\title{
Atlantic Universities \\ Geological Conference \\ 2006
}

A B S T R A C T S

October 26-28, 2006

CONFERENCE HOSTED BY:

THE DAWSON GEOLOGY CLUB

DALHOUSIE UNIVERSITY, HALIFAX, NOVA SCOTIA

Again this year, abstracts from the annual Atlantic Universities Geological Conference (AUGC) are published in Atlantic Geology. This provides a permanent record of the abstracts, and also focuses attention on the excellent quality of the presentations and posters and the interesting and varied geoscience that they cover. The abstracts are published with financial assistance from APICS.

THE EDITORS 
Fine-grained inorganic sediment characterization and size distribution from the last $30 \mathrm{ky}$ in the Eastern Equatorial Pacific as compositional and current intensity proxies

\section{Paul Auerbach \\ Department of Earth Sciences, Dalhousie University, Halifax, Nova Scotia B3H 3J5}

The nature of deep-sea sediments is important for understanding the mechanisms of sediment delivery and deposition to the deep ocean. This study describes and analyzes the size distribution of fine-grained biogenic opal and inorganic bottom sediments in the biologically productive, active upwelling region of the Eastern Equatorial Pacific (EEP). Using the Coulter Multisizer II, samples of biogenic silica, inorganic silt and clay grains are analyzed from various depths in the seabed through a $200 \mathrm{~cm}$ cored interval that spans the age range of $1-30 \mathrm{ky}$ B.P. Downcore variation in grain sizes is inferred to record changes in regional paleocurrent variability as well as fine siliciclastic and opal delivery to the site. Results show that biogenic silica, in the form of opal, coarsens the sediments. However, this effect is not exhibited in the Holocene. Decreased delivery of mineral aerosols is inferred to be a mechanism to enhance the fine grain fraction of the samples. In agreement with other studies, stable paleocurrents are thought to characterize the 15-30 ky B.P period. Comparatively, the 1-15 ky B.P interval shows a more variable flow regime and is attributed to short-term instabilities of deep-water masses. For the paleocurrent reconstruction over latter interval, an anti-correlation is observed with respect to deep-water currents in the North Atlantic suggesting a dynamic inter-play between the Atlantic and Pacific deep water masses in global ocean thermohaline circulation in the Late Quaternary.

\section{A structural analysis of the MAW zone sub-economic rare- earth element deposit, Wheeler River Property, northern Saskatchewan, and the relationship of structures and alteration to possible uranium mineralization}

\section{MARIE BARKer \\ Department of Earth Sciences, St. Francis Xavier University, Antigonish, Nova Scotia, B2G 2W5}

The MAW Zone is a sub economic rare-earth element (REE) deposit near Williams Lake near the southeastern corner of the Athabasca Basin, northern Saskatchewan. The host rocks are the Paleoproterozoic ( 1700Ma) un-metamorphosed quartzrich sandstones of the Athabasca Group, Manitou Falls "d" Formation. This formation consists of fine to coarse sands with minor $(<2 \%)$ mudstone intraclasts. The Athabasca Group in this area is underlain by the high-grade metamorphic and igneous rocks of the Wollaston Group.
The MAW Zone exhibits extensive alteration, including pervasive silicification and hematitization, clay mineral growth, and limonite-staining in breccias and along faults and fractures. In addition, the tourmaline-family mineral dravite occupies the interstices between the sand grains. Geochemical analyses indicate that this alteration zone contains elevated levels of the heavy REE and Y (which behaves like HREE).

In order to document the relationship between mineralization and deformation, detailed mapping was completed that shows the distribution and orientations of lithologies, faults, fractures, alteration, and breccias in an area of about $1 \mathrm{~km}$. Structural analysis of this region combined with information from logs of proximal drill holes and published information of the regional history are used to investigate the sequence of structural deformation and alteration. Preliminary results indicate that the alteration could be related to possible uranium mineralization in the area as it may represent the distal halo of a hydrothermal system responsible for uranium mineralization.

\section{The origin of Cambrian-Ordovician ironstones, Iron} Brook Group, Antigonish Highlands, Nova Scotia

\author{
KIM ELLS \\ Department of Earth Sciences, St. Francis Xavier University, \\ Antigonish, Nova Scotia B2G 2W5
}

Numerous models exist for the genesis of oolitic ironstone deposits. There is general agreement that in most cases the protoliths to these deposits are porous and permeable clastic rocks laid down in a shallow marine environment. However, the source of the iron and related elements, the association of fossiliferous debris with the reduced iron mineralogy, and the origin of features such as oolitic texture are controversial.

The oolitic ironstone and related carbonate of the Ferrona Formation within the Cambro-Ordovician Iron Brook Group, Antigonish Highlands, N.S., are a local representative of widespread iron deposits found in Avalonia and related terranes. Taken together, lithostratigraphic, paleontological, and paleomagnetic data indicate that Avalonia lay along the northern margin of Gondwana at approximately $60^{\circ} \mathrm{S}$ during the Cambrian-Ordovician. The protoliths of the ironstones are thought to have been deposited as part of a continental to shallow marine sequence within a pull-apart basin as evidenced in the local stratigraphy consisting of red fluviatile conglomerate, shale, and distinctive pink limestone.

The ironstone was mined at the beginning of the $20^{\text {th }}$ century. In 1961, the Nova Scotia Department of Mines and Energy, as part of an exploratory program, drilled four holes near Doctors Brook, within the Ferrona Formation. Microscopic and $\mu$ XRD analyses of samples collected from the field and from the core indicate that the ironstones are characterized by quartz grains, siderite spherules, and apatite 
clasts set in a hematite matrix. Oolitic textures are common and are characterized by cores of quartz, hematite, and possibly apatite. Concentric growth patterns are identified by variations in colour and texture, presumably reflecting subtle compositional changes. Calcite, siderite, and ankerite have been identified throughout the Ferrona Formation ironstone in veins, spherules, and the matrix, attesting to the importance of carbonate alteration. Minor sulphides are also present and appear to be in association with calcite veining.

Textural features suggest that the ironstone formed by replacement of sandstone, although the age of this replacement is problematic. Compared to the sandstone, geochemical analyses of the ironstone indicate that it contains lower $\mathrm{SiO}_{2}$ and $\mathrm{Zr}$, and higher $\mathrm{Fe}_{2} \mathrm{O}_{3}, \mathrm{CaO}, \mathrm{MgO}$, and $\mathrm{V}$, as well as greater $\mathrm{LOI}, \mathrm{Al}_{2} \mathrm{O}_{3}$, and $\mathrm{TiO}_{2}$ do not show consistent trends. A further aim of this study is to establish mineralogical and mass balance data in order to better understand the genesis for the oolitic ironstone of the Ferrona Formation.

\section{Seismic stratigraphic and structural characterization of the Snorri J-90 well area, Hopedale Basin, Labrador Sea}

\section{Michael E. Enachescu and Andrew B. Carroll Department of Earth Sciences, Memorial University of Newfoundland, St. John's, Newfoundland, A1B 3X5}

Several large gas discoveries were made during the 1970s to early 1980s exploration cycle in the shallow near-shore Labrador Sea, proving the existence of a rich petroleum system. No follow-up drilling or field development has taken place and only during the past few years has exploration returned with collection of modern 2D seismic data. A re-evaluation of the petroleum potential of the Labrador Sea's Hopdale Basin is long overdue. The Basin Group of the Pan-Atlantic Petroleum System Consortium (PPSC) at Memorial University will perform an integrated regional interpretation using new regional seismic sections collected of the Labrador Sea basins. This study includes the Snorri J-90 discovery well area located in the northern part of the Hopedale Basin. The Hopedale Basin had a complex geological evolution, starting with intra-continental rifting in the Late Jurassic (?) or Early Cretaceous, followed by rifting, transitional crust emplacement, drifting (ocean crust creation) and sea opening cessation. The pre-rift basement has variable seismic proprieties as it varies in age from Paleozoic to Archean and in lithology from carbonates (Ordovician) to granites and metamorphic rocks. The basement reflector is well imaged in the shallow part of the basin and mostly inferred as the basement dives deeper. Several larger depocenters are recognized on the shelf and slope that may contain Mesozoic sequences including mature Cretaceous source rocks and possible Late Jurassic, Kimmeridgian-age sediments. Reservoir intervals are identified in several wells and correlated to seismic markers in order to identify new petroleum leads and assess their potential for large discoveries in the northern Hopedale Basin.

Sourcing artifact native copper using electron probe microanalysis: preliminary results
C. Evans, S.E. Blair, D.C. Hall, and A.F. Park
Geology Department, University of New Brunswick. Box 4400, Fredericton, New Brunswick. E3B 5A3

The Metepenagiag Mi'kmaq Nation is a First Nation community located on the banks of the Miramichi River in northern New Brunswick. In the late 1970s, this community, in partnership with a team of provincial archaeologists, participated in the salvage excavation of the Augustine Mound, a small Early Woodland cemetery that was located within their lands. Aside from providing invaluable insight into religious and burial practices of Early Woodland period Native Americans, the site produced an exceptional assemblage of artifacts, including large numbers of unsmelted copper beads, rings, and tools, and textiles. They are particularly rare in archeological contexts due to the acidity of the soil in this region of the Maritimes.

The copper beads are the most common metal artifacts from the site and a team of researchers from the University of New Brunswick undertook a project to determine their geochemical composition. The overall goal of the project was to establish potential sources for the beads and thus, prospective prehistoric exchange networks. Trace element geochemistry was a powerful means of achieving this goal and one not regularly pursued in archaeology. Hesitancy to use geochemical analytical techniques existed because most methods would destroy the artifacts in question. A non-destructive technique with low detection limits was required, so in a preliminary study, electron probe microanalysis (EPMA) was used to test a bead from the site. After designing a sampling program, 13 sites on the bead were analyzed. Detection limits in the low parts per million were achieved for the key elements. This was important for comparison with compositions determined by other researcher on known prehistoric mine sites in eastern Canada and the United States using more powerful techniques, such as instrumental neutron activation. As a preliminary study, the technique used and the results it produced provided a solid base for the discussion of its implications in future copper sourcing projects. 
Tourmaline chemistry and emerald mineralization at Tsa da Glisza, southern Yukon Territory

\section{Chris Galbraith \\ Department of Earth Sciences, Dalhousie University, Halifax, Nova Scotia B3H 3J5}

Tourmaline is ubiquitous at Tsa da Glisza (formerly Regal Ridge). It is found as porphyroblasts in the greenschists, as phenocrysts in the intruding granite, in quartz-tourmaline veins that cut the schists and as granular black masses found in highly altered gossan or fault zones. The quartz-tourmaline veins are potentially the most important indicator of local emerald mineralization; however, not all quartz-tourmaline veins have associated visible emerald mineralization. Tourmaline acts as an iron-manganese sink. The presence of iron is important in the formation of emeralds. Therefore tourmaline's chemistry may be an identifying factor of more precisely identifying mineralized zones at this property. If so, tourmaline should be more iron-manganese rich in emerald mineralized zones, and more magnesium rich in non-mineralized zones.

\section{Late Pleistocene gravel deposits of ancient Bostwick creek in the Uncompahgre River valley of southwestern Colorado}

\section{S. Kelley ${ }^{1}$, A.M. Hudson ${ }^{2}$, B. Kaproth ${ }^{3}$, AND A. Aslan 4 \\ 1. Department of Earth Sciences, Department of Earth Sciences, Dalhousie University, Halifax, Nova Scotia B3H 3J5 9 2. Montana State University 3. SUNY-Brockport 4. Mesa State College}

The discovery of Lava Creek B ash localities and river gravel outcrops between the Black Canyon of the Gunnison and the San Juan Mountains suggest the presence of a Quaternary paleovalley of Bostwick Creek, a tributary of the ancestral Gunnison River. The geometry and deposits of this paleovalley can be compared with modern valleys to infer change within the basin over the last $640 \mathrm{ky}$. The paleovalley contains lenticular gravel deposits up to $20 \mathrm{~m}$ thick, overlain by fine-grained valley fill sediment up to $55 \mathrm{~m}$ thick. Lava Creek B ash, dated to $640 \mathrm{ka}$, directly overlies the river gravel. Field mapping and GPS surveys suggest that the valley was approximately one mile wide. The percentage of volcanic clasts in the river gravels ranged from $47 \%$ to $82 \%$. Imbrication measurements and the primarily volcanic composition of gravels are evidence that the flow direction of the river was south to north, from the San Juan Mountains.

Downstream divergence of the profiles of ancient Bostwick Creek and the modern rivers suggests rapid recent incision due to knickpoint migration. The Bostwick Creek profile has a much shallower slope than that of the modern Uncompahgre and Gunnison Rivers. This difference in slope is probably explained by an episode of base level fall downstream. The cause of the base level fall was likely due to stream capture by a more energetic river. Using the Lava Creek B age constraint, the maximum incision rate measured was $64 \mathrm{~cm} / \mathrm{ky}$ at Chukar Hill, a location that was probably close to the confluence of Bostwick Park Creek and the ancestral Gunnison River. Comparisons of the elevations of Chukar Hill and the modern the Gunnison River suggest that up to $74 \%$ of the Black Canyon of the Gunnison was incised in the last $640 \mathrm{ky}$. These incision rates are much higher than those found in other areas of the Western U.S., and suggest that high incision rates in the Rocky Mountains may be local phenomena rather than the product of large scale climate change or neo-tectonics.

\section{Tetrapod ichnofossils from the Namurian A} (Mabou Group) of Nova Scotia

\section{Daniel A. Lambert \\ Department of Earth Sciences, St. Francis Xavier \\ University, Antigonish, Nova Scotia B2G 2W5}

Several sets of tetrapod trackways and single footprints were discovered in the sedimentary facies exposed along Bayfield Beach. The sediments occur as interbedded red/brown silts and fine grained sandstones in the Pomquet Formation of the Mabou Group. The depositional environment is interpreted as a meandering river with thick overbank deposits, due to the friable nature of the silts and signs of subaerial exposure such as desiccation cracks, raindrop marks and root casts. Most of the trackways are found within the overbank deposits and are in the form of casts; only one found is still preserved as molds of the animal's feet. Eleven trackways/single footprints have been found showing a wide range in preservation quality (from very poorly preserved to well preserved) and form. The smallest have a width of $\sim 5 \mathrm{~mm}$ and show three preserved phalanges while the larger ones have a width of $\sim 40-55 \mathrm{~mm}$ and show five preserved phalanges on the manus and pes. Most trackways occur at boundaries between the sandstone and silt units and they are distributed throughout the site. They display a range of behaviours, some walking upon the substrate while others appear to have had their bodies partially submerged and preserved paddling traces. 


\section{Form and distribution of gold in the Brunswick No.12 volcanogenic massive sulphide deposit, Bathurst mining camp, New Brunswick}

\author{
Jillian Martin, Sean McClenaghan, \\ AND DAVID LENTZ \\ Department of Geology, University of New Brunswick, \\ P.O. Box 4400, Fredericton, NB, Canada, E3B 5A3
}

The giant Brunswick No. 12 deposit is one of the world's largest $\mathrm{Zn}$-Pb-Cu-Ag-type volcanogenic massive sulphide deposits. Since 1964, this $230 \mathrm{Mt}$ deposit has produced over 106 Mt of massive sulphides grading $3.49 \% \mathrm{~Pb}, 8.85 \% \mathrm{Zn}, 0.36 \%$ $\mathrm{Cu}, 102 \mathrm{ppm} \mathrm{Ag}$ and has an average Au grade of $0.67 \mathrm{ppm}$, with Au values locally exceeding $30 \mathrm{ppm}$ in pyretic sulphides at the north end of the Main Zone ore body. Brunswick No. 12 massive sulphides are hosted by middle Ordovician volcaniclastic rocks atop the Nepisiguit Falls Formation of the Tetagouche Group. Polyphase deformation and greenschist facies metamorphism have resulted in structural thickening of the massive sulphides, and have created four major sulphide lenses which merge with depth.

Massive sulphides at the north end of the Main zone consist of numerous pyritic lenses with variable base metal and elevated gold contents. These lenses consist predominately of thinly layered fine- to medium-grained pyrite, sphalerite, galena, and arsenopyrite with lesser barite, chalcopyrite, tetrahedrite, bismuthinite, molybdenite, and cassiterite/stannite. The shape and distribution of these pyritic lenses relative to the Main ore zone suggests that the north end lenses likely represent a fold repetition of a distal sulphide facies formed on the flanks of a giant hydrothermal system.

Drill core (1 $\mathrm{m}$ intervals) and bulk underground samples ( $3 \mathrm{~kg}$ ) of massive sulphides and host rocks $(\mathrm{n}=58)$ from the 850 $\mathrm{m}$ and $1000 \mathrm{~m}$ levels of the north end main zone were assayed by Atomic Absorption Spectrometry, as well as analysed by Instrumental Neutron Activation Analysis, Inductively Coupled Plasma Mass Spectrometry, and Inductively Coupled Plasma Emission Spectrometry. Gold contents of 43 samples collected from gold-rich massive sulphides in the north end zone average $1.85 \mathrm{ppm}$ and range from $0.31 \mathrm{ppm}$ to $8.20 \mathrm{ppm}$. Spearman Rank correlation coefficients between elements were calculated for the 43 samples of massive sulphides from the north end lenses. Gold exhibits a moderate positive correlation with $\mathrm{Sn}$ $\left(\mathrm{r}^{\prime}=0.58\right), \mathrm{Mo}\left(\mathrm{r}^{\prime}=0.55\right), \mathrm{As}\left(\mathrm{r}^{\prime}=0.48\right)$, and $\mathrm{Sb}\left(\mathrm{r}^{\prime}=0.42\right)$. The Au content of host rocks $(0.36 \mathrm{ppm}, \mathrm{n}=11)$ and cross-cutting quartz veins $(0.060 \mathrm{ppm}, \mathrm{n}=4)$, are very low. Overall, elevated gold contents are accompanied by a high modal abundance of arsenopyrite, cassiterite, molybdenite and tetrahedrite and in places barite. The Au-Sb-As association, absence of native gold and electrum, and the overall abundance of arsenopyrite suggest that $\mathrm{Au}$ is mineralogically bound as an invisible fraction in arsenical pyrite and arsenopyrite.

\section{Nannofossil biostratigraphy of Sauk A-57 and Shubenacadie H-100, offshore Nova Scotia}

\author{
Sara Mason, Victoria Arbour, David Scott, \\ Grant Wach, and Chloe Younger \\ Department of Earth Sciences, Dalhousie University, \\ Halifax, NS, B3H $3 J 5$
}

Drill cuttings were obtained for several wells drilled offshore Nova Scotia, including Sauk A-57 and Shubenacadie H-100. Results from Sauk A-57 show moderate conditions for nannofossil deposition and/or preservation in Pliocene and younger sections, where species diversity and abundances are low. This is attributed to high clastic input and near-shore conditions during deposition. Higher abundances and more diverse assemblages of nannofossils are found in Miocene and older strata, especially during the Eocene, which indicates increasing oceanic influences. Deeper Paleocene sediments show another poorly preserved section. Shubenacadie $\mathrm{H}-100$ showed similar results: the top of the well representing Pliocene and younger intervals have poor to moderately preserved nannofossils with very low diversity. Diversity and abundances increase in Miocene and older intervals. Like Sauk A-57, the Oligocene does not appear to be represented in Shubenacadie H-100.

The rich nannofossil occurrences in the Miocene and older sections show that excellent and dependable stratigraphic subdivision can be achieved. This research will contribute to the development of a more detailed stratigraphic framework for the Tertiary and Upper Cretaceous offshore Nova Scotia.

Growth of clinopyroxenes in a closed system: relationships between $\mathrm{T}-\mathrm{t}$ paths and zonation
Thomas R. Mumford and Cliff S. J. Shaw Geology Department New Brunswick, 2 Bailey Drive, Fredericton, New Brunswick, E3B 5A3

Zoned minerals provide a record of the changing conditions in magma chamber and as such they can be used to determine the dynamic behaviour of subvolcanic magmatic systems prior to eruption. However, interpreting the record preserved in the crystals requires a detailed understanding of the mechanisms that control zonation in minerals. The purpose of this study is to determine if a correlation can be made between the morphology and composition of zoned crystals and the temperature-time (T-t) paths of their formation. A major goal is to compare the experimentally developed zonation patters, to natural zonation patterns in alkaline basaltic lavas from the Eifel volcanic field in Germany.

Synthetic crystals were grown from a leucititic melt (WEG 1999) in a fO controlled, $1 \mathrm{~atm}$, tube furnace with a Eurotherm 
temperature controller. A variety of cooling paths were created with short enough durations, and large enough undercoolings that equilibrium crystal growth (homogeneous crystals), could not occur. In addition to cooling paths, we also performed several experiments with a short heating step to simulate the heating that might take place during an influx of magma. The resulting crystals were imaged with a SEM and high resolution backscattered electron images were collected and processed to highlight growth and zonation patterns. Many of the crystals display hollow cores with feathery crystals indicating that in the first stages of growth the undercooling was high enough to cause quench crystallization. Later growth events produced very complex internal morphologies that are commonly overgrown by a distinctive euhedral rim generated in the final stage of the experiments. The textures produced in the closed system cooling-heating experiments are similar to textures observed in natural volcanic rocks. Further experimentation is required to determine the full range of textures that can be produced, and to determine whether or not this technique can be used to place real time constraints on the cooling and crystallization rates of natural magmas in subvolcanic magma chambers.

Paleoclimate reconstructions using lake sediment geochemistry: implications for GCM validations

\section{Nick Nickerson \\ Department of Earth Sciences, St. Francis Xavier University, Antigonish Nova Scotia B2G 2W5}

Recently, it has been shown that a one thousand year temperature history produced by the ECHO-g General Circulation Model (GCM) was in good agreement with regional borehole paleoclimate reconstructions for the same period. This is an exciting result in the validation of GCM data, but boreholes lack relevant details about small-scale temperature variation and changes surface hydrology, which could be instrumental to GCM validation at high spatial resolutions. Biological and geochemical signals in lake sediment cores have long been used to reconstruct past climates, often with better resolution than is available through borehole techniques. Geochemically, lake sediments can offer insight into past temperatures through the abundance of stable oxygen isotopes found in carbonate shells and sediments. Similarly, watershed paleohydrology can be inferred based on both sediment size analysis and $\mathrm{C} / \mathrm{N}$ ratio of organic matter, which reflects the amount of terrestrial organic matter being deposited in the lake environment and thus, paleoflow conditions. Other lake sediment proxies are also available for examining natural and anthropogenically induced changes in the watershed and lake environments. Stable isotopes of carbon can be used to examine lake paleoproductivity, which may also reflect changes in paleotemperature and paleohydrology. Deposition of bedrock compounds such as sulphate can also be a useful tool to examine the intensity of weathering processes or possibly reveal changes in watershed acidification due to acid rain events. The objective of this study is to undertake a thorough characterization of these geochemical parameters from two lake cores in Antigonish County, and attempt a detailed multi-proxy reconstruction of watershed and lake paleoenvironment. The results of geochemical analyses will be calibrated using available instrumental data for the area, yielding quantitative data on environmental changes in the area. This work could provide a basis for larger and more comprehensive regional studies, which can eventually be used to validate the small-scale changes in temperature and precipitation predicted by GCM's such as ECHO-g.

\section{Uranium and arsenic in ground water in the Grand Pré region in southwestern Nova Scotia: a geochemical and social study}

\author{
Mary A. Samolczyk ${ }^{1}$, Ian S. Spooner ${ }^{2}$, \\ Clifford R. Stanley ${ }^{2}$ and Linda A. Lusby ${ }^{1}$ \\ 1. Environmental Science Program, Acadia University, \\ Wolfville, Nova Scotia, B4P 2R6 2. Department of Geology, \\ Acadia University, Wolfville, Nova Scotia, B4P 2R6
}

Grand Pré is located in the Annapolis-Cornwallis Valley in southwestern Nova Scotia. Groundwater in Grand Pré contains elevated levels of uranium and arsenic. Sixteen well water samples were gathered from residences and businesses in Grand Pré, in August 2006. Information regarding local geology, anthropogenic activity, well construction and data from previous ground water testing was gathered. The concentrations of 72 cations in well water samples were analyzed by ACME laboratories in British Columbia using ICP-MS. Results from preliminary analysis indicate that specific repeated patterns are evident in the concentrations of some cations. In particular, elevated levels of uranium are found in six of the samples, along with elevated levels of arsenic, iron, manganese, and lead in various samples. The contaminants in well water and background knowledge of the area strongly suggest a natural source. The close proximity of elevated levels may be related to locally changing geological conditions, however well design and depth cannot be discounted. Further testing of anions in the well water samples will allow for a more thorough investigation of the geochemical mechanisms affecting the well water by the time the study is completed in early spring 2007. It is a priority to communicate the results of the study and its implications to the residents of Grand Pré, and also to work with the Department of Environment and Labour to increase awareness of the causes of elevated uranium and arsenic in groundwater as well as providing mitigation strategies to those affected. 


\section{Examining the relationship between geological properties of mafic intrusive rocks and construction aggregate durability in New Brunswick}

Holly J. STEWART

Department of Geology, University of New Brunswick, PO Box 4400, Fredericton, New Brunswick, E3B 5A3

Physical testing of bedrock materials used for road building and related construction applications is standard engineering practice. Micro Deval and Los Angeles Abrasion are two of the most common tests used to determine the durability of coarse aggregate materials. These tests are time consuming and expensive. Mineralogical and textural properties of a rock are among the main geological factors that directly influence its mechanical durability and its structural integrity as a reliable construction material. Despite this generally recognized connection, correlation between selected geological properties and standard aggregate engineering tests for road surfacing materials has not been examined in New Brunswick.
This study is examining the relationship between measured mechanical properties of a proposed aggregate material, its textural characteristics, and its mineralogical composition as calculated from available rock chemistries. Available petrographic and rock chemistries from a suite of plutonic and volcanic rocks in northern New Brunswick is being analyzed to determine the link between quantifiable geological data and durability values of these materials established through standard engineering tests. Such an investigation could set the groundwork where applied geological technology could serve as an accurate and reliable means of pre-screening the physical integrity of aggregate materials. This could limit the necessity for extensive engineering mechanical tests resulting in considerable savings of time and money.

The prepared document, in cooperation with New Brunswick Department of Natural Resources, will describe the study including a summary of available literature, a description of methodology, and a discussion of results ending with conclusions and recommendations. 
